\title{
Islamsk teologi som ideologisk slagmark
}

Hvordan ser en islamsk frigiøringsteologi ut? Og hvorfor er en slik teologi så farlig i Egypt at den har ført til rettssak og drapstrusler? 
I det følgende vil jeg presentere noen av de sentrale punktene i Abu Zayds prosjekt, eksemplifisert ved en av hans viktigste bøker, «Mafhum al-nass» (Tekstkonseptet). Jeg vil også sette tankene hans inn i en teologisk sammenheng og prøve å forklare årsakene til de voldsomme reaksjonene på dette prosjektet.

\section{Forenklende forklaringer}

I det store og hele har mainstream arabisk muslimsk teologi vært preget av lukkethet, og slik er det fortsatt. Ved al-Azhar, den store muslimske lærdomsinstitusjonen i Egypt, og andre religiøse høyskoler blir studentene presentert for forenklede sammendrag og forklaringer av hva de store eksegetene fra den islamske gullalderen (ca. 900-I500 e.Kr.) forfattet. Metodene har

TEKST: Jacob Høigilt

I 1996 BLE NASR Hamid Abu Zayd, en egyptisk universitetslærer, erklært som frafallen fra den islamske tro av egyptisk høyesterett, på tross av at han selv hevdet å være en troende muslim. Grunnlaget for dommen var Abu Zayds studier av Koranen og klassisk muslimsk koraneksegese. Som en følge av dette ble han også dømt til å skilles fra sin kone, siden retten mente at islamsk lov ikke godtar at en frafallen er gift med en muslim. Dommen i seg selv var en skandale, og tiltrakk seg mye oppmerksomhet fra forskjellige menneskerettighetsorganisasjoner og arabiske intellektuelle. I I dag lever Abu Zayd i eksil, og tankene hans er fortsatt et ikke-tema i Egypt. Men hvorfor er Abu Zayds tenkning så kontroversiell? Dette er et viktig spørsmål, siden svaret forteller mye om det religiøse og kulturelle klimaet i Egypt i dag. endret seg lite, og det er en uvilje mot å åpne fagene for perspektiver fra andre disipliner. Et resultat av dette er at nytenkning omkring Koranen og den store religiøse arven (al-turath) stort sett kommer fra lekmannsmiljøer - fra ingeniører, filosofer eller litteraturvitere som er interessert i teologi. Så også med Nasr Hamid Abu Zayd, som egentlig studerte arabisk språk ved Kairo universitet da fakultetet bad ham om å begynne å forske på islam fordi dette læresetet var tomt. Litteraturinteressert som han er, dro Abu Zayd med seg litteraturvitenskapelig tenkning inn i studiene av Koranen og de klassiske religiøse utlegningene som utgjør al-turath.

Abu Zayd tar i bruk moderne hermeneutikk i sin tilnærming til Koranen. Det første hovedpunktet i boken hans er at Koranen ble åpenbart i en historisk kontekst, og må tolkes ut fra dette premisset. For Abu Zayd er Koranen en historisk tekst (arabisk: nass), som ble å penbart for menneskene av 
Gud til en gitt tid og på et gitt sted. For å kunne si oss noe i dag, må den derfor studeres ut fra en historisk sammenheng og med moderne vitenskapelige redskaper.

Et av disse redskapene er filosofen Roman Jakobsons berømte kommunikasjonsmodell, hvor det finnes en sender, et budskap og en mottaker, alle med hver sin rolle i kommunikasjonsprosessen. I klartekst betyr dette blant annet at Koranen måtte bruke de "kodene" som fantes i den før-islamske arabiske kulturen for å gjøre seg forstått og akseptert - den gikk inn i den kulturelle konteksten. Bokens første del har en talende tittel: "Teksten i kulturen". Abu Zayd viser her til at verseformen som er brukt i Koranen på 6oo-tallet også ble brukt av seere som stod i kontakt med åndene, eller jinnene. ${ }^{2}$ Koranens form gav altså et signal til araberne om at det her dreide seg om utenommenneskelig kommunikasjon. Gradvis forandret imidlertid Koranens rolle i samfunnet seg, fra å bli formet av denne kulturen til selv å forme den, etter hvert som budskapet ble akseptert og slo rot. Her skal man huske på at Koranen ble åpenbart over en periode på 23 år, slik at det skjedde mye fra første vers ble åpenbart til siste vers ble sendt ned fra Gud: Muhammad gikk fra å være en forfulgt predikant til å bli en politisk-religiøs lederskikkelse som innstiftet en ny samfunnsorden.

Abu Zayd hevder at Koranen endret kulturen på den arabiske halvøy fra å være basert på muntlig overlevering til å bli en tekstkultur. Siden den ble formet av og senere formet den allerede eksisterende kulturen, mener Abu Zayd at Koranen bør leses i den rekkefølgen versene ble åpenbart. I Koranen er versene ordnet på en annen måte, slik at mange av de siste kapit- lene inneholder vers som ble åpenbart svært tidlig. Ved å lese Koranen i kronologisk orden kan man få et klart bilde av hvordan teksten virket i og på kulturen, hevder Abu Zayd. Dette er også det beste utgangspunktet for å drive fortolkning av teksten: den må settes inn i en historisk ramme.

\section{Misforhold}

Hvorfor vil Abu Zayd absolutt bedrive en slik historisk-kritisk koraneksegese? Den klassiske eksegesen, som i stor grad løfter Koranen ut av tid og rom, er jo svært fascinerende og i utgangspunktet også pluralistisk, siden den åpner for et vell av fortolkninger. Det er nok flere svar på dette, men et av de viktigste er Abu Zayds alvorlige anklage mot klassisk eksegese: Ved å overdrive fokuset på Gud og Muhammad har tolkningen til dels mistet en sunn forstå else av teksten, som jo faktisk er selve budskapet, og slik har man skapt en hel del unødvendige problemer og selvmotsigelser i teologien. Misforholdet mellom fokuset på budskapet og avsenderen gjennomsyrer både klassisk og nåtidig teologi, mener Abu Zayd.

Han gir flere konkrete eksempler på dette $\mathrm{i}$ «Tekstkonseptet», som den klassiske diskusjonen rundt hvorfor Koranen ble åpenbart $\mathrm{i}$ porsjoner over en periode på mer enn 20 år. Kunne ikke Gud bare ha sendt ned hele på en gang, og gjort Muhammad i stand til å huske den, spurte eksegetene seg. Det aksepterte og ortodokse svaret, som ble stadfestet rundt I500-tallet, var at alt som er mulig ikke nødvendigvis må skje, og at Koranen ble åpenbart i porsjoner for å svare på spørsmål som ble stilt Muhammad og behandle ulike situasjoner som dukket opp etter hvert. ${ }^{3}$ 
Selv om dette var et godtatt og fornuftig svar ble det imidlertid glemt i stor grad. Den teologiske ash'ari-retningen, som dannet ortodoks skole, var nemlig mer opptatt av å "redde” Guds allmakt; det er jo uakseptabelt at Gud skal måtte tilpasse seg tid og sted! Her gjorde de klassiske

\section{rm \\ Det forste hovedpunktet hans er at Koranen ble åpenbart $i$ en historisk kontekst og må tolkes ut fra dette.}

eksegetene et fatalt mistak, sier Abu Zayd. De har nemlig glemt to ting: tilhørerne som mottok og mottar budskapet, og at Gud valgte å bruke det menneskelige kommunikasjonsmiddelet tekst for å henvende seg til oss. Han viser til at Koranen ikke ble skrevet ned før etter Muhammads død, og ingen på 6oo-tallets arabiske halvøy kunne konsumere så store tekstmengder på en gang. Et annet hovedpoeng for Abu Zayd er at Koranen forholdt seg til samfunnet og dets utvikling, og påvirket denne utviklingen på en avgjørende måte. Derfor er det naturlig at den kom i porsjoner.

\section{Er Koranen evig?}

Imidlertid var Guds allmakt det viktigste, og derfor ble det ortodokse synet en ad hocløsning: Koranen ble sendt ned i ett stykke til "de lavere himler", og kom derfra i porsjoner til Jorden. Dette synet henger sammen med en stor strid i tidlig islamsk tid mellom to ulike teologiske skoler, hvorav den siste ble hegemonisk: de på mange måter rasjonalistiske mu' taziliene og de allerede nevnte ash' ariene. Striden dreide seg om hvorvidt Koranen var skapt av Gud eller ei. Sistnevnte holdt fast på at Koranen var en av Guds egenskaper, ikke en gjerning, og at den derfor var evig, bevart hos Gud på himmelske tavler.

Dette ble også det ortodokse synet, noe som forverrer problemet ytterligere, hevder Abu Zayd. For hvis Koranen er evig, tar man den jo fullstendig ut av sammenheng. Slik blir alt som står i den universelle utsagn, noe som gjør den svært vanskelig å tolke. Og selv om de klassiske eksegetene holdt fast på skillet mellom Koranens "universelle" og "spesifikke" vers ${ }^{4}$, blir lett resultatet av deres teologi at alle vers forstås som universelle. Dette fører til at rigide tolkninger får forrang over tolkninger som tar hensyn til den sosiale og historiske sammenhengen Koranen ble åpenbart i. Slik forkludrer de både tekstforståelsen og utlegningen av islamsk lov, som jo i stor grad baserer seg på Koranen.

Enda alvorligere er det for Abu Zayd at den ortodokse teologien oppløser hele tekstkonseptet. Abu Zayd mener at en tekst per definisjon er et kulturprodukt, og således uløselig knyttet til tid og sted. Bare en eksegese som tar hensyn til den historiske konteksten kan bevare denne siden av Koranen:

I dette bildet som teksten gir av seg selv, gjennom [den eksisterende] kulturen og dens språklige system, fører en fokusering utelukkende på tekstens kilde [Gud] og dens formidler [Muhammad] til at man oppgir tanken på selve tekstens natur $i$ seg selv. Følgelig taper man av syne tekstens funksjon $i$ virkeligheten, og det er dette som har skjedd $i$ den religiøse tenkningen, som har fått monopol på [å snakke om] al-turath. Denne tenkningen er fremdeles virksom i vår kultur $i$ dag. ${ }^{5}$ 
Det andre hovedpunktet $\mathrm{i}$ «Tekstkonseptet» er at fortolkeren av teksten også lever i en bestemt tid og på et bestemt sted, og at tolkningen farges av dette. Her kommer Abu Zayd inn på det som kalles "forståelseshorisonten" i vitenskapsteorien, samt den hermeneutiske tanken om samspillet mellom tekst og mottaker:

En ekseget støtter seg på visse av tekstens egenskaper for å oppdage sammenhenger $i$ teksten, mens en annen bruker andre egenskaper, og dermed oppdager en annen type sammenhenger. [..] Eksegeten forstår det dialektiske forholdet mellom de ulike delene av teksten gjennom sin egen dialog med teksten.

Her ser vi at Abu Zayd slett ikke avskriver Koranens iboende mening eller vil koble alt som står der til en historisk kontekst. Snarere er det snakk om et både-og; en av Abu Zayds alvorligste anklager mot islamsk ortodoksi er at den ser ting i sort og hvitt, og ikke er i stand til å verdsette et mangfold av synspunkter. På samme måte

\section{Fremfor å lese Koranen helt bokstavelig, må man se hvordan budskapet forholdt seg til datiden.}

som det gir interessante resultater å tolke Koranen ut fra en kronologisk ordning av versene, er tekstens nåværende organisering også en verdifull side av den. Man er avhengig av begge for å kunne lese Koranen på en fruktbar måte, mener han. Del to av boken, “Tekstens redskaper", inneholder følgelig en gjennomgang av de stilistiske og grammatiske virkemidlene
Koranen bruker for å meddele seg: upersonlige pronomen for allmenngjøring, implisering, henvisning til andre tekster (Gamle/Nye testamentet), utenomtekstlige episoder osv. Ved hjelp av disse redskapene gir Koranen selv en pekepinn om hvordan man skal tolke. Det finnes for eksempel henvisninger til spesifikke episoder eller hendelser i teksten, men uten at den nevner noen navn på personene som opplevde dem. I stedet kan det stå "hun", "man" eller "de”. Ifølge Abu Zayd er dette Koranens måte å signalisere at selv om det dreier seg om en spesiell hendelse, kan innholdet og budskapet i historien gjelde like mye for dagens mennesker som de personene som opplevde den.

\section{Åpenbaringens retning}

Et vesentlig poeng ved å understreke betydningen av å bruke både en "ekstern” og en "intern" fortolkning av Koranen, er at denne tilnærmingen åpner for å se de større linjene i mye sterkere grad enn den ortodokse eksegesen. Her kommer det inn et viktig begrep som Abu Zayd har utviklet i andre bøker, nemlig “Åpenbaringens retning”. ? Fremfor å lese Koranen helt bokstavelig, må man se hvordan budskapet forholdt seg til datidens normer og skikker, og så overføre retningen til dagens eksegese. I et slikt perspektiv vil ikke fortolkeren mene at kvinner skal arve halvparten av det menn gjør, selv om det står i Koranen. Han vil se at på dette området innførte Koranen en ny og bedre ordning i forhold til den gamle, som ikke gav noen arverettigheter til kvinnen i det hele tatt. Retningen er altså mot likestilling, og i dagens samfunn, som har kommet lengre enn den arabiske halvøy på 6oo-tallet, betyr dette at kvinner bør innrømmes større ret- 
tigheter enn det tekstens bokstav tilsier. Slik kan man utlede generelle og allmenngyldige tolkninger fra "spesifikke" vers, som omhandler konkrete hendelser eller spørsmål på den arabiske halvøy på begynnelsen av 6oo-tallet.

Begge disse hovedpunktene kan virke ganske tilforlatelige på europeere, som har levd med en moderne hermeneutikk i flere århundrer. Når Abu Zayds ideer settes opp mot den tradisjonelle og hegemoniske islamske teologien, blir imidlertid «Tekstkonseptet» til en kruttønne. Med sin doktrine om Koranens uskapthet beveget nemlig ortodoks islam seg inn på en vei hvor det å sette teksten i en historisk kontekst etter hvert ble en trussel mot Koranens integritet som Guds ord. Samtidig førte den teologiske og politiske utviklingen til at enkelte tankeretninger ble dominerende $\mathrm{i}$ så stor grad at de i realiteten har fått status som hellige, et trekk vi finner igjen i Europas inkvisisjon. Den religiøse arven har blitt til

en hellig oppnåelse, som man bare får røre ved hvis man behandler den med cerbødighet og priser den." [..] Arven (al-turath), og ikke religionen, eller riktigere: arven som har blitt til religion, har blitt innlemmet $i$ den hellige sfaren. ${ }^{8}$

En tredje utvikling er den gradvise økningen i de religiøse lærdes (' ulama) religiøse og sosiopolitiske makt. ' Ulama fikk etter hvert monopol på å drive offisiell fortolkning, og bestemte hva som var korrekt tro og hva som var vranglære. I dag befester de denne stillingen i flere land, deriblant Egypt, hvor al-Azhar har en egen komité som vurderer bøker, tv-programmer og så videre, og gjerne får dem forbudt eller sen- surert hvis de "går mot islamsk lov". Abu Zayd viser at parallelt med denne prosessen ble "vanlige" folks adgang til å lese og tolke Koranen redusert. Den sosiale klassen av religiøse lærde oppmuntret heller til en kultur hvor fortolkning var for de få utvalgte, mens den gemene hop skulle nøye seg med å tilbe Gud og ære Profeten og Koranen som hellige objekter istedenfor meningsskapende budskap. Abu Zayd bruker hele den siste delen av boken til å rette et flengende angrep mot en av de virkelig ruvende skikkelsene i islam, alGhazali, (d. IIII), som forente islamsk ortodoksi og den mystiske tradisjonen (sufismen). Nettopp sufismen har blitt gjort til et uttrykk for folkereligiøsitet i Egypt, hvor formen er viktigere enn innholdet, og de forskjellige sufibrorskapene fungerer som sosialt konserverende. Tragedien i dette, sier Abu Zayd, er at selve det islamske budskapet, Koranen, har blitt gjort til en

ting med verdi i seg selv. Det har funnet sted en tingliggjøring av den i kulturen, slik at den har blitt til en pyntegjenstand for kvinner [..] og et ornament man henger på veggen. ${ }^{9}$

Med dette mener Abu Zayd at det finnes smykker med koransitater på, og at det er vanlig å ha kalligrafi med ord eller vers fra Koranen på veggen i arabiske hjem. Slik forblir de store massene bevisstløse i forhold til Koranen som budskapet om islam, mener Abu Zayd, og dette er akkurat det den politiske makten og de religiøse lærde ønsker. For myndighetenes del passer det fint at man ikke nytolker Koranen i forhold til dagens samfunn - det kunne fort føre til ustabilitet og tanker som utfordrer makten. Det religiøse etablissementet er på sin 
side opptatt av å beholde sin autoritet og posisjoner, som er knyttet til den lange tradisjonen det er et resultat av. Nytolkning eroderer deres makt, fordi den fremstiller teologien deres som foreldet og gjør mye av kompetansen deres overflødig.

Imidlertid er det flere faktorer enn bare teologi og sosiopolitiske posisjoner som gjør Abu Zayds budskap til sprengstoff. Han er ikke alene. I Egypt plasserer han seg $i$ en tradisjon av radikale muslimske tenkere som strekker seg tilbake til I920tallet. Både Taha Husayn, ' Ali ' Abd alRaziq og Muhammad Khalafallah er kjente og til dels beryktede personer som stilte spørsmål ved vedtatte sannheter uten å forkaste den religiøse arven. Taha Husayn hevdet at den før-islamske poesien, som de klassiske eksegetene brukte for å forklare ord og uttrykk i Koranen, egentlig ble skrevet etter at Koranen var åpenbart; ' Abd al-Raziq mistet sitt diplom fra al-Azhar fordi han hevdet at Koranen ikke sier noe om statsform, og at Kalifatet derfor ikke hadde noe religiøst grunnlag; og Khalafallah skapte skandale da han på I950-tallet analyserte fortellerkunsten i Koranen ut fra litteraturvitenskapelige metoder - slik gjorde han det jo implisitt klart at Koranen kan tolkes som en hvilken som helst annen tekst.

Felles for alle disse er at de tok i bruk europeiske vitenskapelige metoder eller tankemåter som var et resultat av moderniteten. I de konservative religiøse miliøene delte man selvsagt motstanden mot imperialismen med de mer progressive kreftene i samfunnet. Men de konservative var i tillegg mot europeisk kultur og vitenskap, med den sekulariseringen de innebar. Dette er også en viktig forklaring på reaksjonene mot radikale muslimer; de er på lag med "fienden". I dagens Egypt er forholdet til Vesten så betent at enkle merkelapper kan være nok til å frata folk troverdigheten. Det var dette som skjedde med Abu Zayd. Få av meningsmotstanderne hans argumenterte saklig. Istedenfor ble han kalt for en "ateist" og "vantro" og satt i bås med "vestliggjorte" egyptere, som konservative muslimer bare avskriver uten videre. ${ }^{10}$

\section{En trussel}

En annen forklaring på de sterke reaksjonene Abu Zayd ble utsatt for henger også sammen med forholdet til Vesten: I en situasjon hvor arabiske muslimer føler seg beleiret av fiendtlige makter, er det behov for enhet i rekkene. Abu Zayd sverger til hermeneutikk når han tilnærmer seg Koranen, og det ligger i hermeneutikkens natur at den fører til tolkningspluralisme. Dette blir sett på som en trussel mot islam $i$ en tid da mange føler at religionen er under angrep fra flere hold. Det blir ikke bedre av at Abu Zayd nærmer seg kristen eksegese - Rotraud Wielandt har vist hvordan enkelte av hans formuleringer uten videre kan legges i munnen på den store tyske teologen Rudolf Bultmann. ${ }^{\text {II }}$

Abu Zayd mener for sin del at en slik pluralistisk holdning er det som kan redde den arabiske verden ut av det politiske og sosiale uføret den har kommet opp i. Her er vi ved et punkt som kan forklare hvorfor forfølgelsen av Abu Zayd gikk mye lengre enn det som ble de tidligere radikalerne til del. Han kobler nemlig teoriene sine med et sterkt engasjement for Egypt som folk og land. I forordet sier han at muslimene i dag kjemper for sin eksistens, og at "alliansen" mellom imperialismen og sionismen på den ene siden, og de reaksjonære arabiske 
kreftene på den andre, har blitt en virkelighet som bare blinde ikke kan se. De offisielle religiøse autoritetene spiller på lag med undertrykkende regjeringer, hevder han, og leverer følgende kraftsalve:

Kan forskeren se bort fra de offisielle religiøse mediene og måten de ødelegger folkets sinn på? De beleirer oss med diskusjoner, tv-serier, filmer og fatwaer som vender folk bort fra de virkelige problemene [i livene sine], og tolker religionen til fordel for den herskende makten, som har alliert seg med fedrelandets og religionens fiender. $^{12}$

Det er liten tvil om at Abu Zayd her sikter til Egypts fredsavtale med Israel og landets samarbeid med USA. Både statsmakt og religiøse autoriteter får sine pass påskrevet, og Abu Zayd setter eksplisitt sin forskningsaktivitet inn i rammen av en statskritisk holdning og engasjement for de svake i samfunnet, de som ikke skjønner at de

\section{Europa og USA trykker ham til seg som en "progressiv muslim" og befester de konservatives fordommer.}

blir forledet. Det er ikke til å undres over at slike formuleringer, som går igjen i hele boken, falt enkelte svært tungt for brystet.

Hvis vi setter disse holdningene i sammenheng med Abu Zayds tanke om åpenbaringens retning, som jeg beskrev over, og hvordan en slik tenkemåte vil føre til kvinnefrigjøring i dagens arabiske samfunn, begynner vi å ane hvordan Abu Zayd kan bli sett på som en farlig subversiv tenker av både 'ulama og stat. For å nærme oss en klassifisering av hans teologi og ideologi, er det faktisk nyttig å vende blikket mot SørAfrika og en annen muslimsk tenker som er opptatt av hermeneutikk: Farid Esack. I sørafrikansk terminologi er Esack "farget”, og han var en sentral skikkelse i de sørafrikanske muslimenes aktivisme mot apartheid. I boken «Qur' an, Liberation \& Pluralism» skisserer han en islamsk frigjøringsteologi ut fra en sør-afrikansk kontekst og en moderne hermeneutikk. ${ }^{\mathrm{I}}$ Esack benytter et sitat fra 'Ali ibn Abi Talib, Profetens nevø: “[The Qur' an] does not speak with a tongue; it needs interpreters and interpreters are people" for å vise at fortolkning er kontekstavhengig. Han fortsetter:

The present generation of Muslims, like the many preceding ones, faces the option of reproducing meaning intended for earlier generations or of critically and selectively appropriating traditional understandings to reinterpret the Qur' an as a part of the task of reconstructing society. ${ }^{14}$

Ordene kunne like godt ha kommet fra Abu Zayd, som Esack også nevner som en viktig inspirasjonskilde. Og som Abu Zayd bruker han både den ytre konteksten og de interne sammenhengene i teksten som kilder for sin hermeneutikk. I kapitlet "Hermeneutical Keys" tar han for seg noen viktige ord i Koranen, og viser hvordan de blir brukt på en måte som favoriserer de svake og undertrykte i samfunnet. Som vi har sett, bruker Abu Zayd et kapittel i sin bok til blant annet å gjøre rede for "tekstens redskaper". I det hele tatt er det teoretiske rammeverket hos de to til forveksling likt.

Det er selvsagt mye som er ulikt, også - 
Sør-Afrika er tross alt ikke sammenlignbart med Egypt, og både Abu Zayd og Esack er sterkt knyttet til sine respektive kontekster. Tar man imidlertid høyde for forskjellen mellom de to landene, mener jeg at også Abu Zayd fremstår som en muslimsk frigjøringsteolog. Selv om han ikke begir seg ut på en fullblods korankommentar, har han bygget opp et solid rammeverk for en slik kommentar. Dette rammeverket er karakterisert av åpenhet, stillingtaken for de svake og kritikk av undertrykkende autoriteter.

Her slutter dessverre likhetene. Esack deltok i en vellykket oppstand mot uretten og var med på å bekjempe apartheid i toleransens navn. I Egypt er det tvert imot de konservative, undertrykkende og intolerante kreftene som klarer å mobilisere folket. Abu Zayd og hans likesinnede er marginaliserte og tidvis forfulgte $i$ et land med analfabetisme på over 60 prosent. Svært få av dem han ønsker en bedre framtid er i det hele tatt i stand til å forstå teoriene hans, og lar seg heller overbevise av religiøse autoriteter som fordømmer ham som en frafallen og vestliggjort forræder av islam. Europa og USA trykker ham derimot til sitt bryst som en "progressiv muslim”, og slik befester de bare de konservatives fordommer og mistanker. Det er en ond sirkel. De dominerende religiøse kreftene i Egypt stirrer seg blinde på de moderne tankenes opphav i det imperialistiske Vesten, istedenfor å innse at disse tankene nettopp kan være med på å bekjempe både vestlig og hjemlig undertrykkelse og drive fram en positiv utvikling i de arabiske landene. Så lenge de fortsetter med det, vil utsiktene til Nasr Hamid Abu Zayd og hans likesinnede forbli dystre.

\section{$\cdot f \cdot$}

I Dommen ble delvis båret frem og akkompagnert av et medierabalder fra de konservative religiøse kreftene i Egypt, og Abu Zayd mottok blant annet flere drapstrusler. Som en følge av dette flyktet han og hans kone fra Egypt i I996 og begynte en eksiltilværelse i Nederland.

2 Nasr Hamid Abu Zayd: «Tekstkonseptet». Beirut: al-Markaz al-thaqafi al-' arabi 2000, s. 33-34.

3 Ibid., s. 99.

4 Vers som ikke var bundet til tid og sted, versus vers som henviste til en hendelse eller liknende som skjedde i samfunnet på Muhammads tid.

5 «Tekstkonseptet», s. 57.

6 «Tekstkonseptet», s. I6I.

7 Se Stefan Wild: «Mensch, prophet und Gott im Koran. Muslimische Exegeten des 20. Jahrhunderts und das Menschenbild der Moderne». Mün ster: Rhema 200I, s. 50.

8 Nasr Hamid Abu Zayd: «al-Khitab wal-ta' wil» (Diskurs og fortolkning). Beirut: al-Markaz althaqafi al-' arabi 2000, s. I80.

9 «Tekstkonseptet», s. 297.

Io Rotraud Wielandt: “Wurzeln der Schwierigkeit innerislamischen Gesprächs über neue hermeneutische Zugänge zum Korantext” i Stefan Wild (red.): «The Qur' an as Text». Leiden: Brill I996, s. 262-263.

II Ibid., s. 270.

I2 «Tekstkonseptet», s. 20.

I3 Farid Esack: «Qur' an, Liberation \& Pluralism». Oxford: Oneworld I998.

I4 Ibid., s. 50. 